\title{
Quality Parameters of the Tibiae and Femora of Ostriches
}

\section{author(s)}

Almeida Paz $\mathrm{ICL}^{1}$

Mendes $A^{1}$

Balog $A^{2}$

Almeida $\mathrm{ICL}^{2}$

Martins $\mathrm{MRFB}^{3}$

Vulcano $\mathrm{LC}^{4}$

Komiyama $\mathrm{CM}^{5}$

Professor of the Department of Animal Production of the School of Veterinary Medicine and Animal Science, UNESP/ Botucatu.

2 Undergraduate student of Animal Science of the School of Veterinary Medicine and Animal Science, UNESP/Botucatu.

3 Professor of the Department of Animal Production of the School of Veterinary Medicine and Animal Science, UNESP/ Botucatu.

4 Professor of the Department of Animal Reproduction and Veterinary Radiology of the School of Veterinary Medicine and Animal Science, UNESP/Botucatu.

5 Student of the Post-Graduation Program in Animal Science of the School of Veterinary Medicine and Animal Science, UNESP/ Botucatu.

\section{Mail Address}

Irenilza CL Almeida Paz

Faculdade de Medicina Veterinária e Zootecnia - UNESP

Departamento de Produção Animal

Fazenda Experimental Lageado, $s / n^{\circ}$

C. P. 560

18.618-000. Botucatu, SP, Brazil

E-mail: ibiara@fca.com.br

\section{Keywords}

Bones, bone mineral density, bone quality, bone strength, ostriches.

\section{ABSTRACT}

An experiment was carried out to establish mean bone quality values of the tibiae and femora of ostriches and to evaluate these bones. The right leg bones of 10 males and 10 female African Black ostriches were evaluated. Birds were radiographed immediately after slaughter (during bleeding), with the aid of a portable X-ray apparatus. The obtained radiographs were scanned and bone mineral density means were obtained using software. Bone strength, Seedor index, and dry matter percentage were evaluated and correlated to weight gain during the finishing period (3-13 months of age). Mean values of the evaluated bone quality traits, not previously found in literature, were established. There were no significant differences between males and females in performance or bone quality parameters. It was concluded that male and female ostriches present similar performance and bone quality at slaughter age.

\section{INTRODUCTION}

Bone mineral density is one of the most important parameters to be measured when evaluating bone quality. Bones have a crucial role in normal growth and development of vertebrates. The continuous accretion of cartilage and its subsequent replacement by bone are the main events of the bone elongation process (Howlet, 1980; Banks, 1991; Thorp, 1992; Almeida Paz et al., 2005). The study of bone mineral density in commercial poultry by radiographic optical densitometry using the Cromox $^{\circledR}$ Athena-SAl software is very important for poultry production as this modern technique allows the follow-up of bone mass variation at low cost, providing better understanding and assessment of the bone mineralization process (Louzada, 1994). Bone mineral density can also be measured using other techniques, such as bone mineral composition, bone breaking strength, Seedor index (Seedor, 1995), etc. (Orban et al., 1983).

In ostriches, muscle and skeleton pathologies are related to different causes, particularly to the lack of exercise in young birds, deficient feeding, rearing on inadequate floors, fast weight gain supported by a still developing skeleton, and genetics (Carrer \& Kornfeld, 1999). Leg problems in ostrich chicks may cause considerable mortality (about 5\%). In most instances, this is due to improper bird density and inadequate feeding, leading to significant problems and reduced productivity, rendering operations economically unfeasible (Lima, 2005).

The aim of the present study was to establish mean bone quality values of the tibiae and femora of ostriches, and to verify of bird performance influences the quality of these bones.

\section{MATERIAL AND METHODS}

Radiograph image collections were carried out in a commercial 
processing plant to determine the bone mineral density of tibiae and femora of male and females African Black ostriches.

Birds derived from the same flock, and were all slaughtered on the same day. Ten males and 10 females were radiographed immediately after slaughter (during bleeding), with the aid of a portable X-ray apparatus. After deboning, the bones of these birds were collected and were evaluated as to bone strength, Seedor index, and dry matter content. The values obtained were associated to weight gain during the finishing phase.

Birds were raised as a straight-run flock of 30 individuals - 17 males and 13 females. The flock was established when birds were 3 months, and birds were slaughtered at approximately 13 months of age, or when the flock's average weight was $100 \mathrm{~kg}$. The analyzed performance parameters were: initial weight, weight gain, final weight, and mortality, according to the methodology described by Mendes (1990).

During rearing, birds were submitted to typical farm management. Pelleted feed was supplied three times daily, and water was available ad libitum. The flock was reared in a 600- $\mathrm{m}^{2}$ paddock with Brachiaria decumbens. Table 1 shows the nutritional values of the feeds supplied.

\begin{tabular}{lc}
\hline \multicolumn{2}{l}{ Table $\mathbf{1}$ - Nutritional values of the feed supplied to the studied } \\
Ostriches. \\
Ingredients & $\%$ \\
Ground corn & 44.00 \\
Soybean meal & 24.00 \\
Wheat midds & 16.00 \\
Ground sorghum & 10.97 \\
Calcitic limestone & 1.00 \\
Dicalcium phosphate & 1.82 \\
Dl - Methionine & 0.17 \\
L- Lysine & 0.21 \\
Salt & 0.33 \\
Vitamin and mineral premix & 1.50 \\
Total & 100.00 \\
Dry matter (\%) & 88.09 \\
Crude protein (\%) & 17.47 \\
Metabolizable energy (kcal/kg) & 2600 \\
Ether extract (\%) & 4.21 \\
Total mineral content (\%) & 7.28 \\
Calcium (\%) & 0.93 \\
Phosphorus (\%) & 0.46 \\
Crude fiber (\%) & 7.93 \\
Non-nitrogen extract & 63.11 \\
Total digestible nitrogen & 74.30 \\
\hline Vitamin and minera premix (enrichment/kg feed) vitam A
\end{tabular}

Vitamin and mineral premix (enrichment $/ \mathrm{kg}$ feed): vitamin $\mathrm{A}=24000 \mathrm{UI}$; vitamin $D=7000 \mathrm{Ul}$; vitamin $E=80 \mathrm{mg}$; vitamin $K=3,76 \mathrm{mg}$; vitamin $B 1=1,8 \mathrm{mg}$; vitamin $B 2=7,7 \mathrm{mg}$; vitamin $B 6=1,65 \mathrm{mg}$; vitamin $B 12=40 \mathrm{mcg}$; vitamin $C=125 \mathrm{mg}$; pantothenic acid $=9,2 \mathrm{mg}$; niacin $=40 \mathrm{mg}$; folic acid $=1 \mathrm{mg}$; antioxidant $=50 \mathrm{~g}$; choline $=300 \mathrm{mg}$; biotin $=0,2 \mathrm{mg}$; selenium $=0,27 \mathrm{mg}$; manganese $=160 \mathrm{mg}$; iron $=76 \mathrm{mg}$; copper $=16 \mathrm{mg}$; iodine $=2 \mathrm{mg}$; zinc $=120 \mathrm{mg}$; cobalt $=0,86 \mathrm{mg}$; chromium $=0,02 \mathrm{mg}$.
The ostriches were radiographed immediately after slaughter.

The standardized region for reading was the proximal epiphysis of the right tibia and the distal epiphysis of the right femur. The radiograph technique used was $65 \mathrm{kVp} \times 3 \mathrm{mAs}$, with a $90-\mathrm{cm}$ clearance between the focus and the film. Routine clinical radiological procedures were applied, and the developing and fixing processes were carried out in a standard automatic processor. All radiographic films were of the same brand and batch, with green background, equipped with rare-earth screens and $24 \mathrm{~cm} \times 30 \mathrm{~cm}$ frames. The used phantom (aluminum scale with pre-defined density, used as densitometric reference) was that commonly adopted for densitometry readings in horses, consisting of 25 steps, starting at $0.5 \mathrm{~mm}$ thickness, and increasing every $0.5 \mathrm{~mm}$ up to the 25th step. Figures 1 and 2 show procedures used for reading ostrich tibiae and femora mineral density.

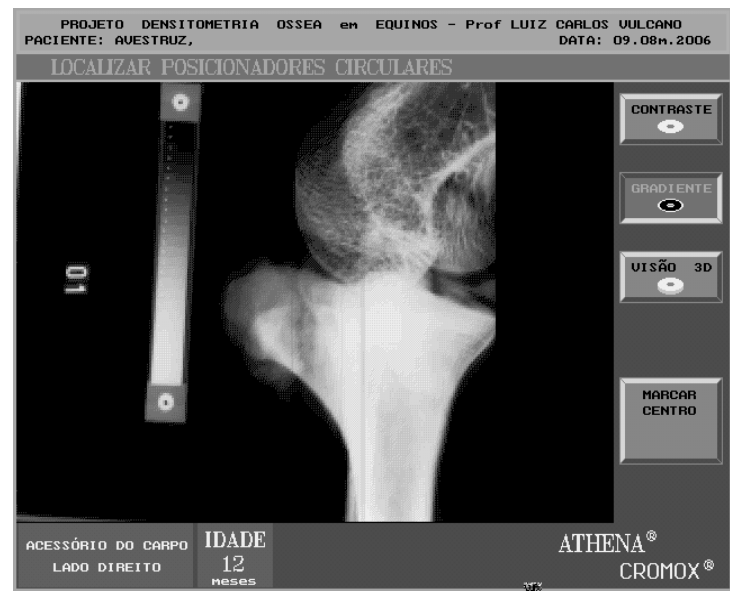

Figure 1 - Radiographic image used to read bone mineral density.

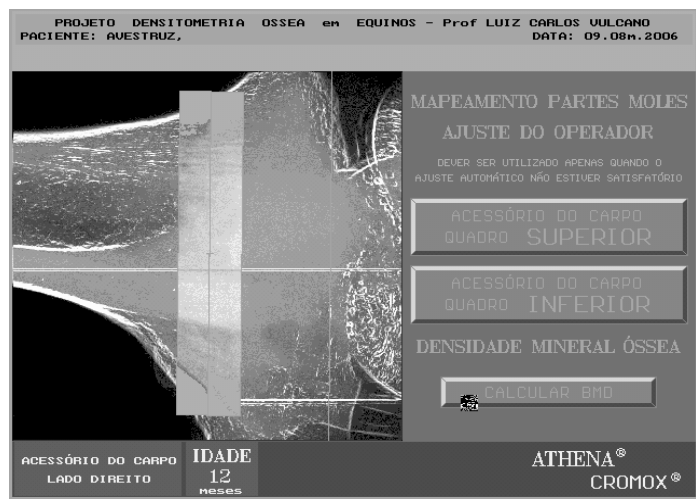

Figure 2 - Frozen image used for limit determination and tibia $B M D$ reading. 
Bone specimens were obtained after muscle removal with the aid of a knife and a scalpel 24 hours after slaughter.

Bone strength analyses were carried out at the Department of Rural Engineering of the School of Agronomic Sciences of UNESP, Botucatu campus, Brazil. An EMIC DL 10000 apparatus was used, regulated to allow a $10-\mathrm{cm}$ diaphysis clearance. This was the maximum clearance obtained for the smallest collected bone, and therefore this clearance was used to the remaining bones. Bone strength values were expressed in kilograms-force.

Seedor indexes were obtained by dividing bone weight by its length, as proposed by Seedor (1995). Bones were measured at their longest length, and were weighed using a semi-analytic digital scale with $0.01 \mathrm{~g}$ accuracy. The Seedor index is an indication of bone density: the higher the value, the denser the bone.

After being submitted to bone strength analysis, bones were taken to the Food Chemical Analyses lab of FMVZ. Dry matter percentage was determined as follows: bones were weighed in an analytical scale, dried in a forced-ventilation oven at $60^{\circ} \mathrm{C}$ for $72 \mathrm{~h}$, after which they were removed from the oven and placed in dessicators until reaching room temperature, and weighed again. Dry matter content was calculated as fresh bone weight minus dried bone weight, and expressed as percentage, according to the method described by Kim et al. (2004).

Results were submitted to analysis of variance using SAEG (1998) statistical package at 5\% significance level. Means were compared by Tukey's test. Correlations between bone quality and performance parameters were tested using Pearson' test (Gomes, 1982), not taking sex into accounts.

\section{RESULTS AND DISCUSSION}

The performance results of the studied flock are presented in Table 2.

There was no difference ( $p>0.05)$ between males and females for the evaluated performance parameters. Although male weight was higher than that of females, it was not statistically different. The values obtained for all parameters are consistent with those found in literature (Carrer \& Kornfeld, 1999; Carvalho, 2006).

Table 3 shows the mean values of bone quality parameters of the tibiae and femora of male and female ostriches. There was no difference $(p>0.05)$ between females and males. This indicated that, when reared under the same conditions up to slaughter, bone quality is not different between male and females ostriches, allowing similar performance improvement as their skeletal systems present the same behavior. In broilers and broiler female breeders, fast weight gain may cause locomotion problems, particularly in males (Macari et al., 2001; Almeida Paz \& Bruno, 2006).

Table 4 presents Pearson's correlations $(p<0.05)$ between live weight, weight gain, and bone quality parameters in the ostriches. Tibia and femur quality traits presented significant correlations, particularly bone mineral density and dry matter. Weight gain was correlated only to live weight. These results suggest that only live weight influenced the evaluated bone quality traits. It was observed that the correlation between bone quality and live weight was more notable for the tibia as compared to the femur, probably because the tibia is a fast-growing bone, and growth rate is influenced by the bird's live weight (Thorp, 1992). BMD and Seedor index of the studied

\begin{tabular}{lcccc}
\hline Table 2 - Ostrich performance. & & & \\
Sex & Av. initial weight $(\mathbf{k g})$ & Av. final weight $(\mathbf{k g})$ & Weight gain (kg) & Mortality (\%) \\
Male & 19.53 & 102.80 & 83.27 & 71.14 \\
Female & 18.99 & 90.13 & $77.21 \pm 0.43$ & 6.67 \\
Mean & $19.26 \pm 0.36$ & $96.47 \pm 0.28$ & 3.40 & $10.00 \pm 0.33$ \\
Coefficient of variation & 2.09 & 6.98 & & 3.35 \\
\hline
\end{tabular}

Table 3 - Mean values of bone mineral density (BMD), bone strength (BS), Seedor index (SI) and dry matter content (DM) of the tibiae and femora of female and male ostriches.

\begin{tabular}{|c|c|c|c|c|c|c|}
\hline Sex & Live weight (g) & Bone & BMD (mm Al) & BR $\left(\mathrm{kgf} / \mathrm{cm}^{2}\right)$ & SI & DM (\%) \\
\hline Male & 103300 & Tibia & 14.16 & 649.27 & 18,93 & 81,13 \\
\hline & & Femur & 6.98 & 298.67 & 16,20 & 76,79 \\
\hline Mean & & & $10.57 \pm 1.42$ & $473.97 \pm 25.02$ & $17,56 \pm 1,24$ & $78,96 \pm 3,82$ \\
\hline Coefficient of variation & & & 1,12 & 1,37 & 1.02 & 1.56 \\
\hline Female & 88967 & Tibia & 13.49 & 462.53 & 17,99 & 77,45 \\
\hline & & Femur & 5.61 & 249.77 & 15,40 & 74,07 \\
\hline Mean & & & $9.55 \pm 1.28$ & $356.15 \pm 21.05$ & $16,69 \pm 1,13$ & $75,76 \pm 3,89$ \\
\hline Coefficient of variation & & & 1,08 & 1,30 & 0.98 & 1.50 \\
\hline
\end{tabular}




\begin{tabular}{|c|c|c|c|c|c|c|c|c|c|c|}
\hline & WG & LW & BMDT & BMDF & BST & BSF & SIT & SIF & DMT & DMF \\
\hline WG & 1.00 & & & & & & & & & \\
\hline LV & 0.61 & 1.00 & & & & & & & & \\
\hline BMDT & - & - & 1.00 & & & & & & & \\
\hline BMDF & - & - & 0.54 & 1.00 & & & & & & \\
\hline BST & - & 0.73 & 0.68 & - & 1.00 & & & & & \\
\hline BSF & - & - & - & 0.69 & - & 1.00 & & & & \\
\hline SIT & - & 0.53 & 0.57 & 0.54 & 0.49 & - & 1.00 & & & \\
\hline SIF & - & - & - & 0.69 & - & 0.50 & 0.47 & 1.00 & & \\
\hline DMT & - & 0.62 & 0.42 & 0.22 & 0.33 & - & 0.69 & - & 1.00 & \\
\hline DMF & - & 0.88 & - & 0.37 & - & 0.41 & - & 0.57 & 0.72 & 1.00 \\
\hline
\end{tabular}

$\mathrm{WG}=$ weight gain; $\mathrm{LW}=$ live weight; $\mathrm{BMDT}=$ tibia bone mineral density; $\mathrm{BMDF}=$ femur bone mineral density $\mathrm{BST}=$ tibia bone strength; $\mathrm{BSF}=\mathrm{femur}$ bone strength; SIT = tibia Seedor index; SIF= femur Seedor index; DMT = tibia dry matter percentage; DMF = femur dry matter percentage. Nonsignificant correlations are not presented, and are expressed as " -".

bones were correlated only to bone quality characteristics, and bone strength and dry matter presented correlation only within the same bone. Skeletal disorders may be triggered when the growth rate of other tissues increase, especially of muscle, without a corresponding increase in bone growth rate (Rennie et al., 1997; Kestin et al., 1999; Rath et al., 1999; Almeida Paz \& Bruno, 2006).

\section{CONCLUSION}

It was concluded that male and female ostriches present similar performance and bone quality at slaughter age, suggesting that, independent of sex, the bones of these birds are able to support the fast weight gain rate that occurs during the finishing phase.

\section{REFERENCES}

Almeida Paz ICL, Mendes AA, Takita TS. et al. Comparision of tecnhiques for tibial dyscondroplasia assessment in broilers chickens. Brazilian Journal of Poultry Science 2005; 7:1:27-32.

Almeida Paz ICL, Bruno LDG. Bone mineral density: review. Brazilian Journal of Poultry Science 2006; 8(2):69-74.

Banks WJ. Histologia veterinária aplicada. 2. ed. São Paulo (SP): Editora Manole; 1991

Carrer CC, Kornfeld ME. A criação de avestruzes no Brasil. Pirassununga (SP): Brasil Ostrich; 1999.

Carvalho M. Avestruz: histórico, maturidade, produtividade, regime alimentar. Revista da Terra [cited 2006 ago 18]. Available from: http://www.revistadaterra.com.br/avestruz1.asp.

Gomes FP. Curso de estatística experimental. Piracicaba (SP): Ed. Nobel; 1982.

Howlet CR. The fine structure of the proximal growth plate metaphysis of the avian tibia: endochondral osteogenesis. Journal of Anatomy 1980; 130:745-768.
Kim WK, Donalson LM, Herrer P. et al. Effects of different bone preparation methods (fresh, dry, and fat-free dry) on bone parameters and the correlations between bone breaking strength and the other bone parameters. Poultry Science 2004; 83(10):16631666.

Lima DL. Fatores que afetam a integridade das pernas em filhotes de avestruz na fase de cria e recria [cited 2005 ago 25]. Available from: www.portaldoavestruz.com.br/materiais.

Kestin SC, Su G, Sorensen P. Different commercial broiler crosser have different susceptibilities to leg weakness. Poultry Science 1999; 78:1085-1090.

Louzada MJQ. Otimização da técnica de densitometria óptica em imagens radiográficas de peças ósseas. Estudo in vitro [tese]. Campinas (SP): Faculdade de Engenharia Elétrica, Universidade Estadual de Campinas; 1994.

Macari M, Furlan RL, Gonzales E. Fisiologia aviária aplicada a frangos de corte. 2.ed. Jaboticabal: FUNEP/UNESP; 2001.

Mendes AA. Efeito de fatores genéticos, nutricionais e do ambiente sobre o rendimento de carcaça de frangos de corte [tese]. Botucatu (SP): Faculdade de Medicina Veterinária e Zootecnia; 1990.

Orban JI, Roland SR, Bryant MM. Factors influencing bone mineral content, density, breaking streng, and ash as response criteria for assessing bone quality in chickens. Poultry Sciennce 1983; 72(3):437-56.

Rath NC, Balog JM, Huff WE. et al. Comparative differences in the composition and biomechanical properties of tibiae of seven-and seventy-week-old male and female broiler breeder chickens. Poultry Science 1999; 78:1232-1239.

Rennie JS, Flemming RH, McCormack HA. et al. Studies on effects of nutritional factors on bone structure and osteoporosis in laying hens. British Poultry Science 1997; 38:417-424.

SAEG- Sistema para Análise Estatística e Genéticas. Manual de utilização do programa SAEG. Viçosa (MG): UFV; 1998. 59p.

Seedor JG. The biophosphanate alendronate (MK-217) inhibit bone loss due to ovariectomy in rats. Journal of Bone and Mineral Research 1995; 4:265-270. 
Thorp BH. Abnormalities in the growth of long bones. In: Whitehead $C C$, editor. Bone biology and skeletal disorders in poultry. Proceedings of the 23th Poultry Science Symposium. Abingdon, Oxfordshire, UK. Abimgdon (UK): Carfax; 1992. p.147-166. 